\title{
A Duna-Dráva Nemzeti Park különböző vizes élőhelyeinek kvalitatív zooplankton vizsgálata I. Rotatoria fauna
}

\author{
KÖRMENDI SÁNDOR ÉS LANSZKI JÓZSEF
}

KöRMENDI S., LANSZKI J.: Investigation of Zooplankton from different water bodies of Duna-Dráva National Park.I. Qualitative investigation of Rotatoria fauna.

Abstract: Different water bodies (river, brook, dead arms, gravel pit lakes, moor,marsh) of Duna-Dráva National Park were analized and 75 Rotatoria taxons were determined in them. The most divers Rotatoria fauna was found in the dead arms (species number of the Rotatoria between 25-41). Much less can be found species in the Dráva river (12-19 species), gravel pit lakes (22 species) and moor (24 species).

\section{Bevezetés}

A zooplankton fauna rendszeres kvalitativ és kvantitatív vizsgálata alapján jellemezhető az adott víztér vízminősége, szaprobiológiai állapota (GuLYẢs,1998), tápanyagellátottsága, ezért szükségszerü a Duna-Dráva Nemzeti Park (DDNP) különbözö jellemző víztereiben az alapállapot rögzitése és a biomonitoring vizsgálatok folytatása.

Kutatásaink során mindezen szempontokat szemelött tartva a zooplanktont alkotó Rotatoria, Cladocera és Copepoda faunát tanulmányoztuk

Jelen dolgozatunkban a DDNP Somogy és Baranya megye területén kijelölt vízterekben (Dráva, Rinya, kavicsbányatavak, holtágak, láp, mocsár) 1999-ben végzett Rotatoria kutatások eredményeit mutatjuk be, a másik két csoport vizsgálatának adatait a következő publikáció tartalmazza.

A Dráva és a Dráva menti vízterek Rotatoria (kerekesféreg) kutatásáról alig jelent meg publikáció.

WOYNÁROVICH (1944) vizsgálatait követően csak a barcsi borókás vizeiböl (RONKAY 1985), a Drávából, a Rinya patakból (GuLYÁs et al., 1995 és KÖRMENDI 1998), valamint a Barcs melletti Kisbók holtágból és a komlósdi égeresből (KöRmENDI 1998) gyüjtött minták adatai állnak rendelkezésre.

Itt szeretnék köszönetet mondani a Janus Pannonius Múzeum Természettudományi Osztályának, személy szerint Dr. Uherkovich Ákosnak munkánk anyagi támogatásáért.

A zooplankton fauna biomonitoringja a Duna-Dráva Nemzeti Park Igazgatóság szervezésében a DDNP Somogy megyei szakaszán 2000-ben elkezdődött.

\section{Anyag és módszer}

A DDNP területén található 12 víztérböl 1999. április 10. -szeptember 24. közötti idöszakban összesen 7 alkalommal történt mintavétel.

A mintavételi helyeket és azok koordinátáit az 1. táblázat tartalmazza. 
1. táblázat: A vizsgált élõhelyek és koordinátáik

\begin{tabular}{|c|c|c|c|c|}
\hline & Községhatár & Víztípus & $\begin{array}{c}\text { Keleti } \\
\text { hosszúság }\end{array}$ & $\begin{array}{c}\text { Északi } \\
\text { szélesség }\end{array}$ \\
\hline 1. & Õrtilos & Élõ Dráva & $16^{\circ} 53^{\prime} 15^{\prime \prime}$ & $46^{\circ} 18^{\prime} 00^{\prime \prime}$ \\
\hline 2. & Õrtilos & Ártéri kavicsbányató & $16^{\circ} 53^{\prime} 35^{\prime \prime}$ & $46^{\circ} 17^{\prime} 30^{\prime \prime}$ \\
\hline 3. & Somogyudvarhely & Kavicsbányató & $17^{\circ} 10145^{\prime \prime}$ & $46^{\prime \prime} 10^{\prime} 40^{\prime \prime}$ \\
\hline 4. & Bélavár & Ó-Dráva, Feltöltõdött holtág & $17^{\circ} 12^{\prime} 10^{\prime \prime}$ & $46^{\circ} 07^{\prime} 10^{\prime \prime}$ \\
\hline 5. & Vízvár & Élõ Dráva & $17^{\circ} 13^{\prime} 45^{\prime \prime}$ & $46^{\circ} 05^{\prime} 00^{\prime \prime}$ \\
\hline 6. & Babócsa & Rinya patak & $17^{\prime \prime} 21^{\prime} 15^{\prime \prime}$ & $46^{\prime \prime} 02^{\prime} 20^{\prime \prime}$ \\
\hline 7. & Barcs & Kisbók, mély holtág & $17^{\prime \prime} 30^{\prime} 55^{\prime \prime}$ & $45^{\prime \prime} 57^{\prime} 05^{\prime \prime}$ \\
\hline 8. & Darány & Nagyberek, Tündérrózsás-tó, & $17^{\prime \prime} 33^{\prime} 25^{\prime \prime}$ & $45^{\prime \prime} 59^{\prime} 30^{\prime \prime}$ \\
\hline 9. & Felsõszentmárton & Mrtvica (Ó-Dráva), feltöltõdött holtág & $17^{\prime} 38^{\prime} 20^{\prime \prime}$ & $45^{\prime \prime} 50^{\prime} 55^{\prime \prime}$ \\
\hline 10. & Drávasztára & Bresztik, Feltöltõdött holtág & $17^{\circ} 50^{\prime} 00^{\prime \prime}$ & $45^{\prime \prime} 48^{\prime} 45^{\prime \prime}$ \\
\hline 11. & Drávaszabolcs & Élõ Dráva & $18^{\prime} 11^{\prime} 40^{\prime \prime}$ & $45^{\circ} 48^{\prime} 45^{\prime \prime}$ \\
\hline 12. & Gordisa & Mattyi-tó, Holtág & $18^{\circ} 15^{\prime} 05^{\prime \prime}$ & $45^{\prime \prime} 47^{\prime} 35^{\prime \prime}$ \\
\hline
\end{tabular}

A mintavételi helyeken $20-100 \mathrm{dm}^{3}$ vizet szürtünk át $25 \mu \mathrm{m}$ szembőségü planktonhálón, majd a mintákat azonnal formalinnal rögzítettük és tartósítottuk.

A helyszíneken megmértük a vízhőmérsékletet, $\mathrm{pH}$-t és vezetőképességet, mely adatokat a mintavételi jegyzőkönyvbe vezettük.

A kerekesféreg fauna kvalitatív és kvantitatív analízisét 5-10 ml térfogatú almintákból négyzetrácsos számlálókamrában végeztük. A nehezen meghatározható fajokat az almintából történő kiemelés és preparálás után azonosítottuk BANCSI (1986) módszerével. A fajmeghatározásokat BANCSI (1986, 1988), BARTOS (1959), KosTE (1978), KuTIKova (1970) munkái alapján végeztük. Az egyedszám, biomassza eredmények és a kutatás statisztikai feldolgozása (diverzitás,egyenletesség, hasonlóság, stb.) a zooplanktont alkotó Cladocera és Copepoda rákcsoportokkal együtt egy későbbi publikáció tárgyát képezik.

\section{A vizsgálatok eredményei}

A vízkémiai mérések szerint a legalacsonyabb $\mathrm{pH}$ és vezetőképesség (össz-só) értékeket a Barcsi Borókásban, míg a legmagasabbakat a holtágakban mértük. Megfigyelhető valamennyi mintavételi helyen az értékek ingadozása, ami a csapadékos időjárással öszszefüggõ hígulási és/vagy bemosódási folyamatokra, sőt vízszennyezésekre is utalhat.

A vizsgált állóvizek a trofitás szempontjából lényegesen különböznek. A kavicsbánya tavak oligo-mezotróf, míg a holtágak eu-politróf vizek (2. táblázat).

A Rotatoria fauna kvalitatív vizsgálata során összesen 75 taxont találtunk. A legalacsonyabb fajszám a Drávából és a Rinya patakból, míg a legtöbb a holtágakból került elő. Meglepő a kavicsbányatavakban a viszonylagos fajgazdagság, és a Barcsi Borókás vizeiben (Darány)az alacsony fajszám (3. táblázat).

A vízterekben meghatározott fajok döntő többsége kozmopolita, euriök faj (ILLIES 1978). Csupán néhány taxon tekinthető ritkának a hazai faunában (pl. Brachionus diversicornis homoceros, B. quadridentatus mehleni, Trichocerca vernalis). A vizsgálatok alapján több melegsztenoterm taxont találtunk (pl. Brachionus falcatus, B. diversicornis, Filinia opoliensis). Az euplanktonikus fajok aránya nem éri el a 40\%-ot, a többi a metafitonban illetve a bentikus élőhelyeken él. A szaprobiológiai indikáció, vagyis a vi- 


\section{2. táblázat: $\mathrm{A}$ pH, a vezetõképesség és a vízhõmérséklet szélsõ- és átlagértékei a vizsgált vízterekben}

\begin{tabular}{|c|c|c|c|c|c|c|c|c|c|c|}
\hline \multirow[t]{2}{*}{ Mintavételi helyek } & \multicolumn{3}{|c|}{$\begin{array}{c}\text { Vízhōmérséklet } \\
\mathrm{C}^{\circ}\end{array}$} & \multicolumn{3}{|c|}{ pH } & \multicolumn{3}{|c|}{$\begin{array}{c}\text { Vezetōképesség } \\
\mu \mathrm{S} / \mathrm{cm}\end{array}$} & \multirow[t]{2}{*}{ Megjegyzés } \\
\hline & Min. & Átl. & Max & Min. & Átl. & Max & Min. & Átl. & Max & \\
\hline \multicolumn{11}{|l|}{ Élõ Dráva } \\
\hline 1. Ôrtilos & 12,5 & 16,9 & 20 & 7,5 & $\overline{7,86}$ & $\overline{8,3}$ & 240 & 318 & 550 & Erősen hordalékos, gyakran rendkivül magas vizállás \\
\hline 5. Vízvár & 13,3 & 18,3 & 22 & 7,9 & 8,06 & 8,3 & 230 & 273 & 320 & u.a. \\
\hline 11. Drávaszabolcs & 16,1 & 18,2 & 20 & 7,7 & $\overline{7,98}$ & $\overline{8,2}$ & 250 & 295 & 340 & 4.a. \\
\hline \multicolumn{11}{|l|}{ Kavicsbánya tavak } \\
\hline 2. Órtilos & 14.2 & 20,8 & 24,5 & 7,8 & 8,18 & 8.8 & 310 & 365 & 520 & Oligo-mezotróf viz, partközeli hínárvegetáció \\
\hline 3. Somogyudvarhely & 15,1 & 21 & 24 & 7,7 & 8,08 & 8,3 & 380 & 445 & 630 & u.a. \\
\hline $\begin{array}{l}\text { 6. Babócsa Rinya } \\
\text { patak }\end{array}$ & 13,5 & 18,8 & 23 & 7.4 & 8,08 & 8,8 & 340 & 563 & 960 & Gyakran igen szennyezett, hordalékos víz \\
\hline $\begin{array}{l}\text { 8. Darány } \\
\text { Nagyberek }\end{array}$ & 16,5 & 18,6 & 20 & 6,4 & 7,1 & 7,5 & 80 & 242 & 420 & Barna víz \\
\hline \multicolumn{11}{|l|}{ Holtágak } \\
\hline 4. Bélavár & 14 & 19,5 & 22 & 7,7 & 8,12 & 8,5 & 430 & 540 & 590 & Eutrỏf víz. Tömeges:Lemna sp.. \\
\hline 7. Barcs Kisbók & 14,5 & 22,1 & 25,5 & 7,1 & 8,01 & 8,6 & 290 & 358 & 500 & \begin{tabular}{|l} 
Eutróf víz,erösen zöld- ćs kékalgás mély víz, \\
partközelben Salvinia sp., Lemna sp. doninancia
\end{tabular} \\
\hline $\begin{array}{l}\text { 9. Felsöszentmárton } \\
\text { Mrtvica }\end{array}$ & 16 & 21,8 & 26 & 7,6 & 8.1 & 8,6 & 310 & 721 & 1140 & $\begin{array}{l}\text { Eutróf víz, közvetlen szerves szennyezés éri. Tömeges: } \\
\text { Utricularia sp., Salvinia sp., Lemna sp., Spirodella sp., }\end{array}$ \\
\hline $\begin{array}{l}\text { 10. Drávasztára } \\
\text { Bresztik }\end{array}$ & 17.5 & 22,4 & 26 & 7,5 & 8,16 & 8,7 & 530 & 683 & 1060 & $\begin{array}{l}\text { Eutróf víz. Tömeges: u.a., mint clöbb és Nuphar sp. } \\
\text { dominancia }\end{array}$ \\
\hline $\begin{array}{l}\text { 12. Gordisa Matlyi- } \\
\text { tó }\end{array}$ & 17,5 & 22,5 & 26 & 7,9 & 8,68 & 9,4 & 600 & 869 & 1140 & Eu-politróf víz, halastó jellegü \\
\hline
\end{tabular}

zek szervesanyagban való gazdagsága, terheltsége szempontjából megállapitható, hogy az előkerült fajok $70 \%$-a $\beta$-mezoszaprób, $12 \%$-a $\beta$ - $\alpha$-mezoszaprób és $18 \%$-a oligo- $\beta$ mezoszaprób vízminőséget jelez, a nagyobb szervesanyag-tartalmú vizek eu-politróf jellegüek. Egy adott víztér vízminősége évszakosan is változik, mert a tavaszi időszakban nagyobb az oligo- $\beta$-mezoszaprób, a nyár folyamán azonban a szervesanyag dúsulással összefüggésban megnő az $\alpha$-mezoszaprób zónára jellemzö taxonok aránya. Ebböl következik, hogy egy adott víztér vízminőség változását szezonális összehasonlításban kell elvégezni. Ugyanez vonatkozik több víztér faunájának összehasonlítására is.

A Drávában és a Rinyában lényegesen kevesebb fajt sikerült kimutatni GulYÁs és munkatársai (1995) vizsgálataival összehasonlítva. Ennek valószínü oka a csapadékos időjárásból és a más okokra visszavezethető vízhozam változásokból fakadó nagymértékü hígulás is lehetett. A Rinyában több alkalommal egyáltalán nem sikerült kerekesférgeket találni, aminek oka ipari eredetü szennyezés volt. A kavicsbányatavak vízminőségét és ezáltal itt előforduló fajösszetételt az intenzív horgászattal összefüggő haltelepítések, haletetések és más horgászattal összefüggö hatások befolyásolják. A szervesanyag dúsulásával összefüggésben a vízi fauna átalakulása rövid időn belül kimutatható lesz.

A feltöltődő holtágak erősen elörehaladottak az eutrofizálódási folyamatban. E vízterekre gyakorlatilag azok a fajok jellemzők, melyek halastavakban is dominánsak (pl. Brachionus calyciflorus, Keratella quadrata, Polyarthra vulgaris stb.). Az intenzív hala- 


\section{3. táblázat: A vizsgált vízterekben talált Rotatoria taxonok listája}

Fajnév

Anuraeopsis fissa (Gosse)

Asplanchna brightwelli Gosse

A. priodonta Gosse

Bdelloidea sp.

Brachionus angularis angularis Gosse

B. budapestinensis Daday

B. calyciflorus calyciflorus Pallas

B. calyciflorus dorcas Gosse

B. calyciflorus amphiceros Ehrenberg

B. calyciflorus spinosus (Wierzejski)

B. diversicornis diversicornis (Daday)

B. diversicornis homoceros Wierzejski

B. falcatus Zacharias

B. quadridentatus quadridentatus Hermann

B. quadridentatus cluniorbicularis (Skorikov)

B. quadridentatus mehleni (Barrois et Daday)

B. rubens Ehrenberg

B. urceolaris O.F. Müller

Cephalodella catellina (O. F. Müller)

C. exigua (Gosse)

C. gibba (Ehrenberg)

Colurella adriatica Ehrenberg

C. uncinata (O. F. Müller)

Conochilus unicornis Rousselet

Dicranophorus uncinatus Milne

Enteroplea lacustris Ehrenberg

Epiphanes clavulata (Ehrenberg)

E. senta (O. F. Müller)

Euchlanis dilatata Ehrenberg

E. lyra Hudson

Filinia longiseta (Ehrenberg)

F.opoliensis (Zacharias)

Hexarthra mira (Hudson)

Kellicottia longispina (Kellicott)

Keratella cochlearis cochlearis (Gosse)

$K$. cochelaris macracantha (Lauterborn)

$K$. cochlearis tecta (Gosse)

K. quadrata (O. F. Müller)

Lecane bulla (Gosse)

L. closterocerca (Schmarda)

L. cornuta (O. F. Müller)

L. elsa Hauer

L. hamata Stokes

L. luna (O. F. Müller)

\begin{tabular}{|l|l|l|l|l|l|l|l|l|l|l|l|} 
1. & 2. & 3. & 4 & 5. & 6. & 7. & 8. & 9. & 10. & 11. & 12. \\
\hline
\end{tabular}

\begin{tabular}{llllll|l|llllll}
\hline & & & + & & & & + & + & + & & \\
\hline & & & + & & & + & & + & + & & + \\
\hline & + & & + & & & & & & &
\end{tabular}

$++$

$+\quad+\quad+\quad+\quad+\quad+$

$++\quad++++++t+$

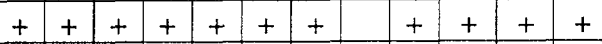

\begin{tabular}{ll|lll|l|l|llllll}
- & + & + & & & + & + & + & + & & + \\
\hline & & & & & + & & & + & & + \\
\hline & + & & & + & & + & & &
\end{tabular}

$++++\quad+\quad++t_{+}^{+}+t_{+}$

\begin{tabular}{|c|c|c|c|c|c|c|c|c|c|c|}
\hline & & & & & & & + & + & & \\
\hline+ & + & + & + & + & + & + & + & + & + & + \\
\hline
\end{tabular}

(1)

\begin{tabular}{llllllll|l|l|l|l|} 
& & + & + & & & + & + & + & + & & + \\
\hline & & & & & & & & + & & + \\
\hline
\end{tabular}


3. táblázat folytatása

\begin{tabular}{|c|c|c|c|c|c|c|c|c|c|c|c|c|}
\hline Fajnév & 1. & 2. & 3. & 4. & 5. & 6. & 7. & 8. & 9. & 10. & 11. & 12 \\
\hline L. lunaris (Ehrenberg) & & & & & & & & & & & & + \\
\hline L. nana (Murray) & & & & + & & & & & & & & + \\
\hline L. obtusa (Murray) & & & & & & & & & + & & & \\
\hline L. quadridentata (Ehrenberg) & & + & & & & & & & & & & \\
\hline L. ungulata (Gosse) & & & + & + & & & & + & & & & + \\
\hline Lepadella patella (O. F. Müller) & & & & + & & & & + & + & + & & + \\
\hline Monommata longiseta (O. F. Müller) & & & & & & & & & & + & & \\
\hline Mytilina ventralis (Ehrenberg) & & & & + & & & & + & + & + & & \\
\hline Notholca acuminata (Ehrenberg) & + & & & & & & & & & & + & \\
\hline Platyias patulus (O. F. Müller) & & + & & + & & & & & + & + & & \\
\hline P. quadricornis (Ehrenberg) & & & & & & & & + & & & & \\
\hline Polyarthra dolichoptera (Idelson) & + & & + & & & & + & & + & + & + & + \\
\hline P. remata (Skorikov) & & & & & & + & + & & & & & \\
\hline P. vulgaris Carlin & + & + & + & + & + & + & + & + & + & + & + & + \\
\hline Pompholyx sulcata Hudson & & & & & & & & & & & & + \\
\hline Scaridium longicaudum (O.F.Müller) & & & & & & & + & & & & & \\
\hline Synchaeta oblonga Ehrenberg & + & & & & & & & & & + & & \\
\hline S. pectinata Ehrenberg & + & + & + & + & + & & + & & & & + & + \\
\hline S. stylata Wierzejski & & & + & & & & & & & & & \\
\hline Squatinella tridentata (Fresenius) & & & & + & & & & & & & & \\
\hline Testudinella patina (Hermann) & & & + & + & & & & + & + & + & & \\
\hline Trichocerca birostris (Minkiewicz) & & + & & & & & & & & & & \\
\hline T. capucina (Wierzejski et Zacharias) & & + & & & & & + & & + & & & \\
\hline T. cylindrica (Imhof) & & & & & & & + & & & & & \\
\hline T. elongata (Gosse) & & & & & & & & + & & & & \\
\hline T. longiseta (Schrank) & + & & & & & + & & & & & & + \\
\hline T. porcellus (Gosse) & & & & & & & & & & + & & \\
\hline T. pusilla (Lauterborn) & + & + & + & + & & + & + & + & + & + & & + \\
\hline T. rattus (O. F. Müller) & & & & + & & & & & + & & & \\
\hline T. vernalis (Hauer) & & & & + & & + & & & & + & & + \\
\hline Trichotria pocillum (O. F. Müller) & & + & + & + & & & & & & & & \\
\hline Fajszám & 19 & 22 & 22 & 32 & 12 & 14 & 27 & 24 & 34 & 41 & 13 & 39 \\
\hline
\end{tabular}

sítás és takarmányozás (etetés) jelentős mértékben felgyorsítja a tápanyagdúsúlási folyamatot, ami nyári kékalga virágzásokat, ezáltal rendszeres oxigénhiányt is okoz. Ilyen algavirágzás figyelhető meg a Mattyi-, a Kisbóki-, és a Mrtvica holtágakon, bár ez utóbbi holtágba közvetlen mezőgazdasági eredetű szennyezés is kerül. A bélavári holtágban a makrofita vegetáció (Nymphaea alba, Nuphar luteum, Ceratophyllum sp. stb.) tömeges elszaporodása csökkenti a szabad vízfelszin területét, minek következetében a trofogén zóna nagysága, ezáltal a víz oxigénellátottsága jelentős mértékben csökken. Mindezek mellett az elpusztult növényzet a szervesanyag-tartalom növekedését okozza és a feliszapolódási folyamatot (szukcesszió) gyorsítja. Ebben a holtágban várható legrövidebb időn belül a kerekesféreg fauna átalakulása. Mindezt bizonyítja a metafitikus és a $\beta$ - $\alpha$ mezoszaprób szervezetek dominanciája.

$\mathrm{Az}$ egyes vízterekben a különböző mintavételi időpontokban talált taxonokat a 4-16. táblázatokban mutatjuk be. A egyedsürüség szélsőértékeit a 17.táblázat tartalmazza. 
4. táblázat: A Drávában előforduló Rotatoria taxonok a mintavételi időpontokban (1. mintavételi hely: Örtilos)

\begin{tabular}{|l|c|c|c|c|c|c|c|}
\hline Fajnév & IV. 10. & V. 21. & VI. 28. & VII. 29. & VIII. 17. & IX. 19. & IX. 24. \\
\hline Asplanchna priodonta & + & + & & + & + & & + \\
\hline Bdelloidea sp. & + & & + & & & + & \\
\hline Brachionus angularis & & + & + & + & & & \\
\hline B. c. calyciflorus & & + & + & + & + & + & + \\
\hline B. diversicornis & & & + & + & & & \\
\hline B. falcatus & + & + & & + & + & & + \\
\hline Euchlanis dilatata & & & + & & + & & \\
\hline Filinia longiseta & + & + & & & + & + & \\
\hline Keratella c. cochlearis & + & + & + & & & + & \\
\hline K. c. macracantha & & & & + & & & \\
\hline K. quadrata & & & + & + & + & & + \\
\hline Notholca acuminata & + & & & & & & \\
\hline Polyarthra dolichoptera & & + & & & & & \\
\hline Polyarthra vulgaris & & + & + & & & & + \\
\hline Synchaeta oblonga & + & & & & & & \\
\hline S. pectinata & & + & + & & + & + & + \\
\hline Trichocerca longiseta & & & + & & & & + \\
\hline Trichocerca pusilla & & & & & + & & + \\
\hline
\end{tabular}

5. táblázat: A Drávában előforduló Rotatoria taxonok a mintavételi időpontokban (5. mintavételi hely: Vízvár)

\begin{tabular}{|l|c|c|c|c|c|c|c|}
\hline Fajnév & IV. 10. & V. 21. & VI. 28. & VII. 29. & VIII. 17. & IX. 19. & IX. 24. \\
\hline Asplanchna priodonta & & & + & & + & & \\
\hline Bdelloidea sp. & + & & + & + & + & & + \\
\hline Brachionus angularis & & + & & & & + & \\
\hline B. c. calyciflorus & & + & + & & + & + & + \\
\hline B. falcatus & & & + & & & + & \\
\hline B. urceolaris & + & & & + & & & + \\
\hline Euchlanis dilatata & + & & + & & + & & + \\
\hline Filinia longiseta & & + & & & + & & \\
\hline Keratella c. cochlearis & + & & & & + & + & \\
\hline K. quadrata & & + & + & + & & & \\
\hline Polyarthra vulgaris & & + & + & & + & + & + \\
\hline Synchaeta pectinata & + & + & & + & & & \\
\hline
\end{tabular}


6. táblázat: A Drávában előforduló Rotatoria taxonok a mintavételi időpontokban (11. mintavételi hely: Drávaszabolcs)

\begin{tabular}{|l|c|c|c|c|c|c|c|}
\hline Fajnév & IV. 10. & V. 21. & VI. 18. & VII. 29. & VIII. 18. & IX. 19. & IX. 24. \\
\hline Brachionus angularis & & & & & + & & + \\
\hline B. c. calyciflorus & & & + & + & & + & + \\
\hline B. diversicornis & + & + & & + & & + & + \\
\hline B. falcatus & & & + & & + & & \\
\hline B. urceolaris & & & & & & + & \\
\hline Filinia longiseta & + & & + & & & & \\
\hline Keratella c. cochlearis & & & & & + & + & \\
\hline K. c. tecta & & & & & & + & + \\
\hline K. quadrata & + & + & + & & & & \\
\hline Notholca acuminata & & + & & & & & \\
\hline Polyarthra dolichoptera & & + & & + & & + & \\
\hline P. vulgaris & + & + & + & & + & & \\
\hline Synchaeta pectinata & + & + & + & & & & \\
\hline
\end{tabular}

7. táblázat: A Rinya patakban előforduló Rotatoria taxonok a mintavételi időpontokban (6. mintavételi hely: Babócsa)

\begin{tabular}{|l|c|c|c|c|c|c|c|}
\hline Fajnév & IV. 10. & V. 21. & VI. 28. & VII. 29. & VIII. 17. & IX. 19. & IX. 24. \\
\hline Bdelloidea sp. & + & & + & & + & & + \\
\hline Brachionus angularis & + & & + & & & & + \\
\hline B. c. calyciflorus & + & & & + & & & \\
\hline B. falcatus & & & + & & + & & \\
\hline B. urceolaris & + & & & + & + & & + \\
\hline Filinia longiseta & & & + & & & & \\
\hline Keratella c. cochlearis & + & & + & + & + & & \\
\hline K. c. macracantha & & & + & & & & \\
\hline K. quadrata & & & & + & + & & + \\
\hline Polyarthra remata & + & & & & & & \\
\hline P. vulgaris & & & + & + & + & & \\
\hline Trichocerca longiseta & & & + & & & & \\
\hline T. pusilla & + & & & & & & + \\
\hline T. vernalis & + & & & & & & \\
\hline
\end{tabular}


8. táblázat: A Barcsi Borókás ( Nagyberek, Tündérrózsás-tó) Rotatoria faunája a mintavételi idöpontokban (8.mintavételi hely: Darány) $\mathrm{D}=$ Domináns taxon

\begin{tabular}{|l|c|c|c|c|c|c|c|}
\hline Fajnév & IV. 10. & V. 21. & VI. 28. & VII. 29. & VIII. 18. & IX. 19. & IX. 24. \\
\hline Anuraeopsis fissa & & + & & & & & + \\
\hline Bdelloidea sp. & + & & + & + & & + & + \\
\hline Brachionus c. dorcas & + & & & & & & \\
\hline B. diversicornis & & + & + & & + & + & + \\
\hline B. falcatus & & & + D) & & & + & + \\
\hline B. q. quadridentatus & & + (D) & & + & & & + \\
\hline B. urceolaris & + & + & & + & & & \\
\hline Cephalodella gibba & & & & + & & & \\
\hline Colurella adriatica & & & & + & + & & \\
\hline C. uncinata & & + & & & & & \\
\hline Epiphanes senta & & & & & + & + & \\
\hline Euchlanis dilatata & + & & & + & + & + & + \\
\hline E. lyra & & & & + & & & \\
\hline Keratella c. cochlearis & & & + & & + & & + \\
\hline K. quadrata & + & + & & & + & + & + \\
\hline Lecane bulla & & & & + & & & \\
\hline L. hamata & & & & + & & + & \\
\hline L. ungulata & & + & & & & & \\
\hline Mytilina ventralis & & & & + & + & & \\
\hline Platyias quadricornis & + & + & & + & & & \\
\hline Polyarthra vulgaris & & + & & + & + & & + \\
\hline Testudinella patina & & & & & + & & + \\
\hline Trichocerca elongata & & & + & & & & + \\
\hline T. pusilla & & & & & + & + & + \\
\hline
\end{tabular}


9. táblázat: A kavicsbányatavak Rotatoria faunája a mintavételi időpontokban (2. mintavételi hely: Örtilos) $\mathrm{D}=$ Domináns taxon

\begin{tabular}{|l|c|c|c|c|c|c|c|}
\hline Fajnév & IV. 10. & V. 21. & VI. 28. & VII. 29. & VIII. 17. & IX. 19. & IX. 24. \\
\hline Asplanchna priodonta & + & + & & + & & & + \\
\hline Bdelloidea sp. & + & & + & & & & + \\
\hline B. c. calyciflorus & + & & + & + & & + & \\
\hline B. diversicornis & & & $+(\mathrm{D})$ & & + & & \\
\hline B. falcatus & & & + & + & & $+(\mathrm{D})$ & + \\
\hline Dicranophorus uncinatus & + & & & & & & \\
\hline Euchlanis dilatata & & + & + & & & & \\
\hline Kellicottia longispina & $+(\mathrm{D})$ & & & & & & \\
\hline Keratella c. cochlearis & + & + & & & & + & \\
\hline K. quadrata & & $+(\mathrm{D})$ & & & + & & \\
\hline Lecane quadridentata & + & & & & & & \\
\hline Platyias patulus & & & & + & & & \\
\hline Polyarthra vulgaris & + & + & + & & & + & + \\
\hline Synchaeta pectinata & + & & & + & & + & + \\
\hline Trichocerca capucina & & & & + & & + & \\
\hline T. pusilla & & + & & & + & & + \\
\hline Trichotria pocillum & + & + & & & & & \\
\hline
\end{tabular}

10. táblázat:A kavicsbányatavak Rotatoria faunája a mintavételi időpontokban (3. mintavételi hely: Somogyudvarhely) $\mathrm{D}=$ Domináns taxon

\begin{tabular}{|l|c|c|c|c|c|c|c|}
\hline Fajnév & IV. 10. & V. 21. & VI. 28. & VII. 29. & VIII. 17. & IX. 19. & IX. 24. \\
\hline Asplanchna priodonta & + & & + & + & + & + & + (D) \\
\hline Brachionus c. calyciflorus & & + & + & + & + & & + \\
\hline B. c. dorcas & + & & & & & & \\
\hline B. c. spinosus & & & & + & + & & \\
\hline B. diversicornis & & + & + & & & & \\
\hline B. q. quadridentatus & & & + & & & & \\
\hline B. urceolaris & & + & & & & + & + \\
\hline Epiphanes clavulata & & & & & + & & \\
\hline Euchlanis dilatata & & + & & + & & & + \\
\hline Filinia longiseta & + & $+(\mathrm{D})$ & & & & & \\
\hline Keratella c. cochlearis & $+(\mathrm{D})$ & $+(\mathrm{D})$ & & & & + & \\
\hline K. c. macracantha & & & & & + & & \\
\hline K. quadrata & & + & + & & & & \\
\hline Lecane luna & & & & & + & & \\
\hline L. ungulata & & & & & + & & \\
\hline Polyarthra dolichoptera & + & & & + & + & & + \\
\hline P. vulgaris & + & + & + & & & + & \\
\hline Synchaeta pectinata & & & & + & & + & + \\
\hline S. stylata & & & & + & & & \\
\hline Testudinella patina & + & & & & & & + \\
\hline Trichocerca pusilla & & & + & + & & + & + \\
\hline Trichotria pocillum & + & & & & & & \\
\hline
\end{tabular}


11. táblázat: A holtágak Rotatoria faunája a mintavételi időpontokban (4. mintavételi hely : Bélavár) $\mathrm{D}=$ Domináns taxon

\begin{tabular}{|l|c|c|c|c|c|c|c|}
\hline Fajnév & IV. 10. & V. 21. & VI. 28. & VII. 29. & VIII. 17. & IX. 19. & IX. 24. \\
\hline Anuraeopsis fissa & & & & & & + & \\
\hline Asplanchna brightwelli & + & + & & + & + & + & + \\
\hline Bdelloidea sp. & + & + & + & + & + & + & + \\
\hline Brachionus angularis & & + & & & + & & \\
\hline B. c. calyciflorus & + & + & & & + & + & \\
\hline B. c. dorcas & + & & & & & & \\
\hline B. c. spinosus & & + & & & & + & \\
\hline B. falcatus & & + & + & & & & + \\
\hline B. q. quadridentatus & & & + & & & & + \\
\hline C. uncinata & & & & & + & & + \\
\hline Conochilus unicornis & & + & + & & & + & \\
\hline Euchlanis dilatata & + & $+(\mathrm{D})$ & + & + & + & + & \\
\hline Filinia longiseta & + & & & & & & \\
\hline Keratella c. macracantha & & & + & + & + & & \\
\hline K. cochlearis tecta & & + & + & & & & \\
\hline K. quadrata & & & & + & + & + & \\
\hline Lecane elsa & & + & & & & & \\
\hline L. hamata & & & + & & & + & \\
\hline L. nana & & & & + & + & & \\
\hline L. ungulata & & & + & & & + & \\
\hline Lepadella patella & & + & & & & & + \\
\hline Mytilina ventralis & & & + & & & & \\
\hline Platyias patulus & & + & & & + & & \\
\hline Polyarthra vulgaris & + & & + & & & & + \\
\hline Synchaeta pectinata & + & + & & & & & \\
\hline Squatinella tridentata & & & + & + & & & \\
\hline Testudinella patina & & & & & & + & \\
\hline Trichocerca pusilla & & + & & & + & & + \\
\hline T. rattus & & & + & & & + & \\
\hline T. vernalis & & + & & + & & & \\
\hline Trichotria pocillum & + & + & & & & & \\
\hline
\end{tabular}




\section{2. táblázat: A holtágak Rotatoria faunája a mintavételi időpontokban (7. mintavételi hely: Barcs-Kisbók) $\mathrm{D}=$ Domináns taxon}

\begin{tabular}{|l|c|c|c|c|c|c|c|}
\hline Fajnév & IV. 10. & V. 21. & VI. 28. & VII. 29. & VIII. 17. & IX. 19. & IX. 24. \\
\hline Asplanchna brightwelli & + (D) & & & + & + (D) & + & + \\
\hline Bdelloidea sp. & & + & & & & + & + \\
\hline Brachionus angularis & + & + & & & & & \\
\hline B. c. calyciflorus & & & + & + & + & & + \\
\hline B. c. dorcas & + & & & & & & \\
\hline B. c. amphiceros & & & & + & & & \\
\hline B. c. spinosus & & & + & + & + & + & \\
\hline B. diversicornis & & & & & + & $+(\mathrm{D})$ & $+(\mathrm{D})$ \\
\hline B. falcatus & & & $+(\mathrm{D} !)$ & $+(\mathrm{D} !)$ & & & \\
\hline B. q. quadridentatus & & & & + & + & + & \\
\hline B. rubens & + & & & & & & \\
\hline B. urceolaris & & + & & & & & \\
\hline Conochilus unicornis & & + & & & & + & \\
\hline Euchlanis dilatata & & $+(\mathrm{D})$ & & + & & & + \\
\hline Filinia longiseta & + & & & & & + & \\
\hline Keratella c. cochlearis & + & & & + & + & + & \\
\hline K. c. macracantha & + & & & + & & & \\
\hline K. c. tecta & & & + & + & & + & \\
\hline K. quadrata & + & & & & & + & + \\
\hline Polyarthra dolichoptera & + & & & & & & \\
\hline P. remata & & + & & & & & \\
\hline P. vulgaris & & & + & & + & + & + \\
\hline Synchaeta pectinata & + & & & & & & \\
\hline Scaridium longicaudum & & + & & & & & \\
\hline Trichocerca capucina & & + & & & & & \\
\hline T. cylindrica & & & + & + & & & \\
\hline T. pusilla & & & & + & + & & + \\
\hline
\end{tabular}


13. táblázat: A holtágak Rotatoria faunája a mintavételi időpontokban (9. mintavételi hely: Felsőszentmárton-Mrtvica) $\mathrm{D}=$ Domináns taxon

\begin{tabular}{|c|c|c|c|c|c|c|c|}
\hline Fajnév & IV. 10. & V. 21. & VI. 28 & VII. 29. & VIII. 18. & IX. 19. & IX. 24 \\
\hline Anuraeopsis fissa & & & & + & + & + & \\
\hline Asplanchna brightwelli & + & + & & + & + & + & + \\
\hline Bdelloidea sp. & + & & & & + & + & \\
\hline Brachionus angularis & $+(\mathrm{D})$ & & & + & & & \\
\hline B. c. calyciflorus & + & + & + & + & & + & + \\
\hline B. c. dorcas & & & & + & + & & \\
\hline B. c. spinosus & + & & & & & & \\
\hline B. diversicornis homoceros & & + & + & & + & & \\
\hline B. falcatus & & & & + & & & + \\
\hline B. q. quadridentatus & & & & & & & + \\
\hline B. q. mehleni & & + & & + & & & \\
\hline Cephalodella catellina & & & & & + & & \\
\hline C. exigua & & & & & & + & \\
\hline Colurella uncinata & & & & + & + & & \\
\hline Epiphanes senta & & & & + & + & & \\
\hline Euchlanis dilatata & & & & + & & + & + \\
\hline Filinia longiseta & & & + & + & + & & \\
\hline Keratella c. cochlearis & + & & & & & & \\
\hline K. c. tecta & & & & & + & + & + \\
\hline K. quadrata & + & $+(\mathrm{D})$ & + & & & & $+(\mathrm{D})$ \\
\hline Lecane bulla & & + & + & + & & & \\
\hline L. closterocerca & & & + & & & + & \\
\hline L. hamata & & & & & + & & + \\
\hline L. luna & & & & & & + & + \\
\hline \begin{tabular}{|l} 
L. obtusa \\
\end{tabular} & & & & + & & & \\
\hline Lepadella patella & + & & & & & + & \\
\hline Mytilina ventralis & & & + & & + & & \\
\hline Platyias patulus & & & & + & + & & \\
\hline Polyarthra dolichoptera & & + & & + & & & \\
\hline P. vulgaris & & & & & + & + & + \\
\hline Testudinella patina & & & & + & & & \\
\hline Trichocerca capucina & & & & + & & & \\
\hline T. pusilla & & + & + & & + & + & + \\
\hline T. rattus & & & & & + & + & \\
\hline
\end{tabular}


14. táblázat: A holtágak Rotatoria faunája a mintavételi időpontokban (10. mintavételi hely: Drávasztára-Bresztik) $\mathrm{D}=$ Domináns taxon

\begin{tabular}{|c|c|c|c|c|c|c|c|}
\hline Fajnév & IV. 10. & V.21. & VI. 18. & VII. 29. & VIII. 18. & IX. 19. & IX. 24. \\
\hline Anuraeopsis fissa & & & + & & & & \\
\hline Asplanchna brightwelli & + & + & + & + & & + & + \\
\hline Brachionus angularis & + & $+(\mathrm{D})$ & + & & & & + \\
\hline B. budapestinensis & & & + & & + & & + \\
\hline B. c. calyciflorus & + & + & + & + & + & + & + \\
\hline B. c. dorcas & & & & + & + & & \\
\hline B. c. amphiceros & & & + & + & & & \\
\hline B. c. spinosus & + & & & & & & \\
\hline B. diversicornis & & & + & & + & + & \\
\hline B. diversicornis homoceros & & + & & & & & \\
\hline B. falcatus & + & + & + & + & & & \\
\hline B. q. quadridentatus & & + & & + & & & + \\
\hline B. q. cluniorbicularis & & & & + & & & \\
\hline B. q. mehleni & & . & + & & & & \\
\hline B. rubens & & + & . & & & & \\
\hline B. urceolaris & + & + & + & + & & & \\
\hline Colurella adriatica & & & + & & & & + \\
\hline Enteroplea lacustris & & & + & & & & \\
\hline Epiphanes senta & & . & & & + & + & + \\
\hline Euchlanis dilatata & + & + & + & & & & \\
\hline Filinia longiseta & $+(\mathrm{D})$ & + & & & & & \\
\hline F. opoliensis & & & & + & & & \\
\hline Hexarthra mira & & + & + & + & & + & \\
\hline Keratella c. cochlearis & & + & & & & + & + \\
\hline K. c. macracantha & & + & & & & & \\
\hline K. c. tecta & & $+(D)$ & + & & & & \\
\hline K. quadrata & $+(\mathrm{D})$ & & & & + & + & + \\
\hline Lecane cornuta & & & + & + & & & \\
\hline L. hamata & & & & + & & & \\
\hline L. luna & & + & & + & & & \\
\hline Lepadella patella & & & + & & & & + \\
\hline Monommata longiseta & & & + & & & & \\
\hline Mytilina ventralis & & & + & & + & & \\
\hline Platyias patulus & & & & & + & & \\
\hline Polyarthra dolichoptera & + & + & + & & & & \\
\hline P. vulgaris & & & + & & + & + & + \\
\hline Synchaeta oblonga & + & + & & & & & \\
\hline Testudinella patina & & & & + & & + & \\
\hline Trichocerca porcellus & & + & & & & & \\
\hline T. pusilla & & + & & + & & + & + \\
\hline T. vernalis & & + & & + & & & + \\
\hline
\end{tabular}


15. táblázat: A holtágak Rotatoria faunája a mintavételi időpontokban (12. mintavételi hely: Gordisa - Mattyi-tó) $D=$ Domináns taxon

\begin{tabular}{|c|c|c|c|c|c|c|c|}
\hline Fajnév & IV. 10. & V.21. & VI. 18. & VII. 29 & VIII. 18. & IX. 19 & IX. 24. \\
\hline Asplanchna brightwelli & + & + & + & + & & + & + \\
\hline Brachionus angularis & & + & $+(D)$ & & & + & \\
\hline B. budapestinensis & & & & & + & & \\
\hline B. calyciflorus calyciflorus & & + & $+(\mathrm{D})$ & $+(\mathrm{D})$ & + & + & + \\
\hline B. c. dorcas & & & & + & + & & \\
\hline B. c. amphiceros & & 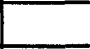 & + & + & & & \\
\hline B. c. spinosus & + & + & & & & & \\
\hline B. diversicornis & + & + & + & + & & + & + \\
\hline B. falcatus & & & $+(\mathrm{D})$ & $+(\mathrm{D})$ & $+(\mathrm{D})$ & $+(D)$ & + \\
\hline B.q. quadridentatus & & + & + & & & & + \\
\hline B. q. cluniorbicularis & & + & & & & & + \\
\hline B. q. mehleni & & + & . & + & & & \\
\hline B. rubens & & & + & & + & & \\
\hline Colurella adriatica & & & + & + & & & \\
\hline C. uncinata & + & & & & + & + & \\
\hline Epiphanes senta & + & & & & & + & \\
\hline Euchlanis dilatata & + & + & & + & & & \\
\hline Filinia longiseta & & + & & & + & & + \\
\hline Hexarthra mira & & + & + & & & & \\
\hline Kellicottia longispina & & + & + & & & & \\
\hline Keratella c. cochlearis & & + & + & + & + & & \\
\hline K. c. tecta & + & & + & & + & & \\
\hline K. quadrata & + & + & + & + & & & \\
\hline Lecane closterocerca & + & & . & + & & & + \\
\hline L. cornuta & & & + & + & & & + \\
\hline L. elsa & & + & & & & & \\
\hline L. hamata & & & & + & + & & \\
\hline L. luna & & & & & + & + & \\
\hline L. lunaris & + & & & & & & \\
\hline L. nana & + & & & & & & \\
\hline L. ungulata & & & + & & & & \\
\hline Lepadella patella & & & & & + & + & \\
\hline Polyarthra dolichoptera & & & & + & & & \\
\hline P. vulgaris & & + & + & + & & & + \\
\hline Pompholyx sulcata & & + & & & + & & \\
\hline Synchaeta pectinata & & + & + & & & & + \\
\hline Trichocerca longiseta & & & + & & & & \\
\hline T. pusilla & & & & & + & + & + \\
\hline T. vernalis & & & + & & & & \\
\hline
\end{tabular}


16. táblázat: A Rotatoria egyedszám szélsőértékei az egyes mintavételi helyeken ind./100 1

\begin{tabular}{|l|c|}
\hline Mintavételi hely & Egyedszám \\
\hline 1. Örtilos, élö Dráva & $9-196$ \\
\hline 2. Örtilos, ártéri kavicsbány ató & $12-345$ \\
\hline 3. Somogy udvarhely, kavicsbány ató & $12-420$ \\
\hline 4. Bélavár, Ó-Dráva-feltöltődő holtág & $42-3520$ \\
\hline 5. Vízvár, élő Dráva & $10-180$ \\
\hline 6. Babócsa, Rinya patak & $14-110$ \\
\hline 7. Barcs, Kisbók-mély holtág & $211-368050$ \\
\hline 8. Darány, Nagyberek mocsár & $196-1548$ \\
\hline 9. Felsőszentmárton, Mrtica-Ó-Dráva-feltöltődő holtág & $140-2650$ \\
\hline 10. Drávasztára, Bresztik-feltöltődött holtág & $120-4250$ \\
\hline 11. Drávaszabolcs, élő Dráva & $9-310$ \\
\hline 12. Gordisa, Mattyi-tó, holtág & $365-45622$ \\
\hline
\end{tabular}

\section{Irodalom}

BANCSI I. 1986: A kerekesférgek (Rotatoria) kishatározója I. Vizügyi Hidrobiológia 15. VÍZDOK Budapest: $1-172$.

BANCSI I. 1988: A kerckesférgek (Rotatoria) kishatározója II. Vizügyi Hidrobiológia 17. VíZDOK Budapest: $173-577$.

BARTOS E. 1959: Virnici-Rotatoria. Fauna CSSR,Praha,15: 1-969.

Gulyás P.-BANCSI I.-ZsugA K.V. 1995: Rotatoria and Crustacea fauna of the Hungarian watercourses. Misc.Zool. Hung. 10: 21-47.

GulYẢs P. 1998: Szaprobiológiai indikátorfajok jegyzéke. Vízi Természet- és Környezetvédelem 6. KGI Budapest: 1-96.

ILLIES J. 1978: Limnofauna Europea. G.F.Verlag: 54-91.

Koste,W.1978: Rotatoria - Die Radertiere Mittcleuropas. Überordnung Monogononta I-II.

KöRMENDI S. 1998: Rotatoria és Crustacea vizsgálatok a Duna-Dráva Nemzeti Park különbözõ víztereiben. Dunántúli Dolg. Term.tud.Sorozat 9,Pécs: 37-42.

KuTIKOVA L.A. 1970: Kolovratki Fauna USSR.-Fauna USSR, 104.

RONKAY L. 1985: Adatok a barcsi borókás kerekesféreg-faunájának ismeretéhez (Aschelminthes,Rotatoria). Dunántúli Dolg. Term.tud.Sorozat 5,Pécs:67-70.

Woynárovich E. 1944: A Bellyci-tó, Kopácsi tó, valamint a Duna és Dráva limnológiai viszonyainak keresztmetszete. Albertina,1: 34-64. 


\title{
Investigation of Zooplankton from different water bodies of Duna-Dráva National Park.I. Qualitative investigation of Rotatoria fauna
}

\author{
SÁNDOR KÖRMENDI \& JózSEF LANSZKI
}

There were found 75 Rotatoria taxons in the investigated water bodies of Duna-Dráva National Park (Dráva, Rinya, gravel pit lakes, dead arms, marsh, moor). Most of occured species are cosmopolitan, well-adaptable species of high ecological tolerance. Some rare rotatorian species occured, such as Brachionus diversicornis homoceros, Brachionus qudridentatus mehleni, Trichocerca vernalis. The number of taxons can be significantly increased by systematical research of the different habitats (for example benton, metaphyton). The number of species can be determined by different factors in the river (Dráva) and in the brook (Rinya) (for example water pollution, discharge fluctuations), that is why there can be extremely fluctuation of a number of taxons. Based on the occurence of the saprobic indicator species it can be ascertained that the eutrophication process speeds up in the gravel pit lakes and dead arms and leads to water quality problems because of different human effects (for example intensive fish stocking, fish nutrition, influent of different organic matter). The most significant purpose of the futher researches is to determine the changes of water quality of different water habitats by biomonitoring.

\author{
Authors' addresses: \\ Sándor KöRMENDI \\ Dr. József LANSZK! \\ University of Kaposvár \\ H-7400 Kaposvár \\ Po. Box 16. \\ HUNGARY
}

